\title{
The "Pasteurization Process" of Local-Grounded Strategies in the Primary Health Care in two Experiences of the Global South (Brazil and Chile)
}

\author{
Eliezer Araújo ${ }^{1}$, Sebastián Medina $^{2}$, Esteban Figueroa $^{3}$, Marília Gurgel de Castro ${ }^{4}$
}

\begin{abstract}
This article explores the process of two emerging local-grounded strategies born in the context of Primary Health Care, in rural locations in Brazil and Chile, using a post-colonial framework. Initially rooted in local health needs and socio-cultural characteristics, both experiences undergo a process of modelling and subsequent replication by the governance of health systems, with an asymmetric power/ knowledge structure. We used a Collective Case Study as a methodological strategy and used field records, in-depth interviews and a critical literature review. As a result, we saw that the social participation experienced in communitybased health systems has the potential to generate high-impact initiatives, considering local realities. At the same time, through the metaphor of "pasteurization", we emphasize that hegemonic governance can remove the "living components" of these types of local strategies, causing them to lose their emancipatory capacities.
\end{abstract}

Key words: primary health care, postcolonial studies, public health, ecology of knowledge, social participation.

1 Faculty of Economics - University of Coimbra. E-mail: araujo@tuta.io;

2 Faculty of Economics - University of Coimbra. E-mail: sebamedi@gmail.com;

3 Puerto Montt Rural Health Team. E-mail: estebanfigueroaoliva@gmail.com;

4 Nursing School of Coimbra. E-mail: castro.mariliag@gmail.com; 


\section{O "Processo de Pasteurização" de Estratégias de Base Local na Atenção Primária à Saúde em duas Experiências do Sul Global (Brasil e Chile)}

\section{Resumo}

Este artigo explora o processo de duas estratégias emergentes de base local nascidas no contexto da Atenção Primária à Saúde, em localidades rurais do Brasil e Chile, utilizando um framework pós-colonial. Inicialmente enraizadas nas necessidades sanitárias locais e nas características socioculturais, ambas as experiências sofrem um processo de modelagem e posterior replicação pela governança dos sistemas de saúde, com estrutura assimétrica de poder/conhecimento. Utilizamos um Estudo de Caso Coletivo, como estratégia metodológica e utilizamos registros de campo, entrevistas em profundidade e uma revisão crítica da literatura. Como resultado, vimos que a participação social vivida nos sistemas de saúde de base comunitária têm o potencial de gerar iniciativas de alto impacto, considerando as realidades locais. Ao mesmo tempo, através da metáfora da "pasteurização", destacamos a governança hegemônica pode retirar os "componentes vivos" desses tipos de estratégias locais, fazendo-os perder suas capacidades emancipatórias.

Palavras-chave: atenção primária à saúde, estudos pós-coloniais, saúde pública, ecologia de saberes, participação social. 


\section{Introduction}

Since the declarations of the Alma-Ata Conference on Primary Health Care (PHC) in 1978 (WHO, 1978), neoliberal globalization has advanced in the countries of the Global South, in which many States are under strong pressure to reduce, focus and minimize health policies. (Rivero, 2003; Ugalde and Jackson, 1995).

In Latin America, minimalist health policies were imposed in the last 40 years. The aspiration of an "universal access to health" supported by good-quality PHC systems, has had to deal with a perverse history of authoritarian and self-proclaimed "progressive" governments (Homedes \& Ugalde, 2011; Kemp, 2008; Tetelboin \& Salinas, 1984).

With the massive mobilizations of indigenous and territorial defense organizations from the 1990s this polices were forced to face the multicultural reality of our countries and to open the health system to new emerging actors that became visible (Boccara, 2007; Cuyul, 2012). In this direction, some institutional reconfigurations enabled a diversity of experiences in the local PHC, with a greater diversity of actors, knowledge and practices. But also, with evident restrictions and exclusion mechanisms, by the established power (Araújo \& Medina, 2016; Medina, Mendonça, \& Manrique, 2015).

Our goal is to make a critical reflection of those new dynamics, between democracy and public health, highlighting the risks of normalization and the imposition of knowledge and powers. We use a conceptual framework based on Postcolonial Studies and the Boaventura Santos' proposal of "a sociology of absences and emergencies" (Santos, 2003).

We started from two real experiences in which we were involved and in which we can perceive the matrix of capitalist, colonial and patriarchal power that sustains neoliberal globalization, being reproduced within this type of "local processes". We also highlight, for each experience, what we think are the seeds of a possible "counter-hegemonic globalization" (Santos, 2001; 2006).

The conceptualizations of postcolonial studies can be useful to think the contemporary forms of health/illness processes in the Global South (Porto, 2003). This wide project of research began to question the relationship between modernity and colonial domination. The 
"non-modern" subjects are considered "subhumans" to be exploited and subordinated to the capitalist colonial metropolis (Young, 2003, p. 2).

For Quijano and Wallerstein (1992) this global-power matrix is supported on three fundamental axes: capital, race and gender, which are intrinsic to the contemporary globalization process. Three forms of oppression that determines the health-illness processes (Breilh, 2003). The modernity is not only a form of economic and social domination, but also a cognitive domination. For Santos (2000) this "metonymic reason" actively produces erasure of certain entities, knowledges and practices. They becomes "invisible, unintelligible and/or disposable in an irreversible way" (Santos, 2003, pp. 246).

We use the metaphor of pasteurization in a complex social process in order to amplify its controversial character. Basically, the "pasteurization process" is the utilization of high temperatures in food to kill the potentially pathogenic microorganisms. This has two results: 1) a large part of the living organisms involved in the generation of food, is eliminated (for example, in cheese and wine) and 2) this food is homogenized for its preservation and "safe" consumption.

As a metaphor, the pasteurization process allows us to highlight: 1) how the living components, present in the new health care strategies disappear, under the aegis of hegemonic power and 2) how these strategies lose their singularity and relevance, to the extent that they become replicable and "safe" models.

\section{Method}

We conducted our research as a "collective case study", according to the guidelines of Stake (2003), Yin (2010) and Baxter and Jack (2008). For Yin (2010), the case study is an empirical investigation of a contemporary phenomenon, in depth and in its real context. For Stake (2003), the researcher must: delimit and conceptualize the object of study; identify data patterns; look for alternative interpretations and develop statements or generalizations.

We arbitrarily selected, based on our field experience, within the scope of community health, two individual cases of emerging experiences, with the aim of highlighting common problems such as: the strength of local-based experiences, in friction with asymmetric structures of power and knowledge. We also consider the guidelines of Burau \& Blank (2006) 
and Gerschman (2008) to build a comparative matrix between the two target countries of the study (Table 1).

Table 1- Matrix of comparison of the countries, public health polices and models of the study

\begin{tabular}{|c|c|c|c|}
\hline DIMENSIONS & INDICATORS & BRAZIL & CHILE \\
\hline \multirow[t]{2}{*}{$\begin{array}{l}\text { Strategic } \\
\text { direction of } \\
\text { Health Care }\end{array}$} & \begin{tabular}{lrr} 
Legal & \multicolumn{2}{c}{ framework, } \\
social & rights and \\
health & &
\end{tabular} & $\begin{array}{l}\text { Federal Constitution } \\
\text { recognizes health "as the right } \\
\text { and the duty of the State". } \\
\text { (1988, Art. 196) }\end{array}$ & $\begin{array}{l}\text { Constitutional Right of } \\
\text { "Health Access Protection " } \\
\text { by the State }(1980, \text { Art.19). }\end{array}$ \\
\hline & $\begin{array}{l}\text { Key actors in } \mathrm{PHC} \\
\text { Governance }\end{array}$ & $\begin{array}{l}\text { Municipal manager assumes } \\
\text { full management of health } \\
\text { services in its territory. }\end{array}$ & $\begin{array}{l}\text { Municipal administration of } \\
\text { PHC centers. Technical } \\
\text { support by the Provincial } \\
\text { Health Services. }\end{array}$ \\
\hline \multirow[t]{2}{*}{$\begin{array}{l}\text { Provision and } \\
\text { organization of } \\
\text { PHC }\end{array}$} & $\begin{array}{l}\text { PHC Types of health } \\
\text { unit }\end{array}$ & $\begin{array}{l}\text { Basic Health Units (FHU), } \\
\text { which vary in size and number } \\
\text { of teams. }\end{array}$ & $\begin{array}{l}\text { Family Health Center, } \\
\text { Community and Familiar } \\
\text { Health Center, Rural Health } \\
\text { Center, which vary in size and } \\
\text { number of teams. }\end{array}$ \\
\hline & Main services offered & $\begin{array}{l}\text { Primary and preventive } \\
\text { medical care. }\end{array}$ & $\begin{array}{l}\text { Primary and preventive } \\
\text { medical care. }\end{array}$ \\
\hline $\begin{array}{l}\text { Social } \\
\text { Participation in } \\
\text { Health }\end{array}$ & $\begin{array}{l}\text { Forms of } \\
\text { representation of users }\end{array}$ & $\begin{array}{l}\text { Local health councils and } \\
\text { intersectoral commissions, } \\
\text { subordinated to the National } \\
\text { Health Council. }\end{array}$ & $\begin{array}{l}\text { Participative local diagnostics, } \\
\text { integration of the Provincials } \\
\text { Service Network Meetins. }\end{array}$ \\
\hline \multirow[t]{5}{*}{$\begin{array}{l}\text { PHC experience } \\
\text { analysed }\end{array}$} & & $\begin{array}{l}\text { Model of mental health care, } \\
\text { Family Health Unit in Sobral, } \\
\text { Ceará. }\end{array}$ & $\begin{array}{l}\text { Model of rural health with } \\
\text { culture pertinence, Service of } \\
\text { Health, Reloncavi. }\end{array}$ \\
\hline & Population involved & 9.525 & 12.372 \\
\hline & $\begin{array}{l}\text { Geographical } \\
\text { extension }\end{array}$ & $2.122 \mathrm{Km}^{2}$ & $1.673 \mathrm{kms}^{2}$ \\
\hline & $\begin{array}{l}\text { Number of officials } \\
\text { involved }\end{array}$ & 34 & 72 \\
\hline & $\begin{array}{l}\text { Duration of the } \\
\text { experience }\end{array}$ & 2009 and 2010 & 2008 to the present \\
\hline
\end{tabular}

Source: adapted from Giovanella et al. (2012). 


\section{Results}

Case 1: A model of mental health care, in the setting of a Family Health Unit in Sobral, Ceará, Brazil

This experience arises in the context of Family Health Strategy (FHS) in Sobral, a small city of the State of Ceará, Northeaster region of Brazil. The intervention were carried out by standard's PHC teams, with contributions from "Family Health Support Teams" and "Multiprofessional Residency of Family Health".

The FHS is the first contact of the population with health services. It represents the coordination of health care, family-focused attention, community involvement and cultural competence. It's composed of medical professionals, nurses, nursing auxiliaries and community health agents (Camargo-Borges \& Cardoso, 2005; Brasil, 2012).

In the year of 2009, the FHU "Alto da Brasília" was perceived the need for an intervention in mental health. Before this experience of intervention, there was only consultation with a specialist doctor, fragmented from the team's work, and did not result in effective therapeutic goals. Some patients using psychiatric medication did not receive a systematic medical review and no care plan was established.

To solve these problems, several meetings were scheduled between the standard FHU team and the support team in order to deepen the democratic debate around the issue. Likewise, discussions were held on with community leaders, in community associations, carried out with the participation of health teams. A reorganization of mental health care was proposed to overcome the care model focused on the medical procedure, stimulating the development of an interdisciplinary and multi-professional clinic. In practice this was due to several actions: analysis of each case by a multi-professional team, family approach and construction of therapeutic plans.

The entire health care team was involved in building on the reorganization of care for psychiatric patients. It was perceived that this experience of reorganization, has had significant gains towards comprehensive health care, accessibility and equity and the link between health professionals and users. The patients had more opportunities to proactively participate in their care process. At the end of the experience, municipal management 
considered it successful, recognising it as a strategy that could be multiplied to other territories (Silva et al., 2010).

\section{Modeling and replication by municipal power level}

The follow-up of the experience did not turn out as expected. The idea of reproducing elements of the model, such as the multi-professional outpatient clinic and the review of the medication flow, were not sufficient to guarantee the PHC staffing commitment or patient participation. PHC professionals showed resistance to changes in the work process, especially in a scenario of precariousness. The mental health was not seen as a priority. The lack of support from municipal management and the disarticulation of the health team, due to the departure of some key professionals and changes in the support teams, led to the gradual loss of strength of the original initiative.

Finally, the attempt to replicate the mental health model for PHC, without prior recognition of local health needs and without creating spaces for democratic cooperation at work, prevented the project from developing with the same vitality in other health facilities.

\section{Case 2: A model of rural health with culture pertinence, in the setting of the Health Service in Reloncaví province, Chile}

In 2007 the former Reloncaví Health Service (RHS) requests a qualitative research and diagnosis on the state of rural health in its jurisdiction. At the country level, there were concern about the poor results obtained in the rural areas. In the RHS, a work team of five health officials takes shape, four physicians and one anthropologist. A journey was made, in which focal groups were held with neighbors of urban and rural areas, as well as with professionals of low complexity hospitals, and the municipalized PHC centers.

From this journey, a great gap was noticed between governmental public health policies and the local reality. This led to a unitary hypothesis: "rural health has lost its purpose". From there, the proposal for the construction of territorial, public and autonomous health teams emerged (Carvajal et al, 2007). Meetings were held with senior officials from the Ministry of Health, who requested advice on redesigning the national rural health program.

The pilot experience that became more representative was the Puerto Montt Rural Health Team (PMT), with the arrival of human, physical and monetary resources to support 
the HRH. The experience was a profound transformation of the health care model, with the idea of "reconnecting" the personal stories and sensitivities of PMT members, with the collective history of each specific territory, seeking to strengthen cultural identities and overcome the decontextualized format the hegemonic biomedical model (Menéndez, 1983).

The PMT was divided into four interdisciplinary teams that gave continuity to the health care and began to create an autonomous work, producing information not only about the health care needs of each locality but on other dimensions who impact heavily on the health/illness process, such as livelihood, food, affection and ecological transgression.

The role of Health Committees (HC) has been reevaluated, and neighbors (the community) have come together to discuss local health problems around Rural Health Centers. The number of HC's assets multiplied within the commune and many promotion, researches and organization activities were gradually created.

\section{Modeling and replication at central level}

By the end of 2009 the results of these "test experiences" were presented to senior officials of the Ministry of Health, with the intention of delivering a proposal for the development of health in all rural areas of the country. The team was invited to participate in the "refoundation of the national rural health strategy" and the reconfiguration of the pharmaceutical kit available at the all the rural health centers.

The replication of the strategy at the national level necessarily required a standardization process, like other health programs. This involved adapting the experience to a linear structure format, in order to diagnose a problem, establish objectives and then design a battery of production indicators, associated with wellness components. Key concepts such as "cultural relevance in public policies" or "territorial perspective" were reduced to "essentialist definitions" and the design of strategies aimed at specific cultural groups in a colonial axis of reproduction of otherness. The idea of public policies adjustable to a set of dynamic and proactive elements that are part of the cultural matrix of a territory, was rejected and the concept of territory itself was reduced to its meaning of geographical proximity. 


\section{Discussion}

The "progressive forces" in both States have left profound marks on public health. In fact, the Constitutions of both countries enshrine the right to health and offer this notion through the PHC strategy. The both experiences were born from the criticisms of the hegemonic governance of the PHC. Especially, the extension of the medicalization and the fragmentation of the human being, society and nature (Cannellotto, \& Luchtenber, 2010).

We believe the metaphor of pasteurizattion was useful to observe the disappearance of the initial actors and the homogenization of the strategy. This is a complex social process that requires a fine "decryption" of its internal logics. The governance's pasteurization has, al least, two dimensions involved: scales and the translations.

In the transfer of a local to national scale, as was intended in the case of Chile, or a regional scale, as was the case of Brazil, the hegemonic planners take control back. An unquestioned "logical framework" is imposed, reducing the complexities of the experiences to an essential number of objectives, goals, resources and concrete actions. The concrete actors who established a new relationship between them and walk together on unthinkable paths, disappear from the planning table. The governance of local health strategies requires a fine level of socio-cultural, ecological and sanitary detail. Meanwhile, the level of generalization for the governance of regional and national health strategies required few contextual details of the typical bureaucratic planning instruments.

Multiple translations are part of these processes. At the local level, PHC members and patients from different classes, genders and cultures establish dialectic spaces around the common code of appropriation of the PHC. Soon, it is necessary a new code with space to different struggles and utopias in tension (Castro, 2010; Meneses, 2016; Ribeiro, 2005). This generates the visibility of hidden forms of discrimination and social injustice. It is a singular gaze, that generates a new practice of care. 


\section{Conclusion}

It is in this complexity that we can see the divergence between colonial planning and the intersubjectivity of a territory. In both experiences highlighted in this text, the Territory is assessed as a subjective, dynamic and flexible variable. A historical moment and contextualized by a multiplicity of active and participative subjects.

The concept of territoriality present in the two experiences was fundamental in the original planning. The territory acquired a status not only geographic, but full of critical desire and a culturally constructed geography, shaped by emotions, stories and identities. 


\section{Bibliography}

ARAÚJO, E.; MEDINA, S. Rezadeiras nos cuidados de saúde primários no Brasil, rumo a uma ecologia dos saberes ou apropriação pela biomedicina? Atas do IX Congresso

Português de Sociologia, Lisboa: Associação Portuguesa de Sociologia, 2017. Retrieved from: $<$ https://associacaoportuguesasociologia.pt/ix_congresso/docs/final/COM0250.pdf $>$.

BAXTER, P.; JACK, S. Qualitative case study methodology: Study design and implementation for novice researchers. The Qualitative Report, 13(4), 544-559, 2008.

Retrieved from: < $\underline{\text { http://nsuworks.nova.edu/tqr/vol13/iss4/2>. }}$

BREILH, J. Epidemiología critica: Ciência Emancipadora e Interculturalidad. Buenos Aires: Editorial Lugar, 2003.

BOCCARA, G. Etnogubernamentalidad. La formación del Campo de la Salud Intercultural en Chile. Chungara, Revista de Antropología Chilena, 39(2), p.185-207, 2007.

BURAU, V.; BLANK, R. H. Comparing health policy: an assessment of typologies of health systems, Journal of Comparative Policy Analysis, Abingdon, v.8, p.63-76, 2006. Retrieved from: $<\underline{\text { http://www.tandfonline.com/doi/abs/10.1080/13876980500513558>. }}$.

CANNELLOTTO, A.; LUCHTENBER, E. Medicalización y sociedad: lecturas críticas sobre la construccion social de las enfermedades. Buenos Aires: Universidad Nacional de San Martin, 2010.

CAMARGO-BORGES, C.; CARDOSO, C. L. A psicologia e a estratégia saúde da família: compondo saberes e fazeres. Psicologia e Sociedade, Porto Alegre, v.17, n.2, p.26-32, 2005

Retrieved from: $<$ http://www.scielo.br/scielo.php? $\underline{\text { script }=\text { sci_arttext\&pid }=\mathrm{S} 010271822005000200005 \& \operatorname{lng}=\mathrm{pt} \& \mathrm{nrm}=\mathrm{iso}>}>$. 
CARVAJAL, Y.; CARVAJAL, J.; FIGUEROA, E.; IBACACHE, J.; JARAMILLO, F.; WINKLER, M. Propuesta para el desarrollo de la salud en el ámbito rural. Cuadernos Médico Sociales, 47(3), 139-154, 2007. Retrieved from: $<$ https://biblat.unam.mx/pt/revista/cuadernos-medico-sociales-santiago/articulo/ propuesta-para-el-desarrollo-de-la-salud-en-el-ambito-rural> .

CASTRO, E. Metafísicas caníbales. Líneas de antropología postestructural (Stella Mastrangelo, Trad. $1^{\circ}$ ed.). Buenos Aires: Katz Editores, 2010.

CUYUL, A. Salud intercultural y la patrimonialización de la Salud Mapuche en Chile. In Moreno, et al., (Orgs.), Ta iñ fijke xipa rakizuameluwun: Historia, colonialismo y resistencia desde el país Mapuche (pp. 263-284). Santiago/Chile: Ediciones Comunidad de Historia Mapuche, 2012.

GERSCHMAN, S. Políticas comparadas de saúde suplementar no contexto de sistemas públicos de saúde: União Europeia e Brasil. Ciência \& Saúde Coletiva, Rio de Janeiro, v.13, n.5, p.1441-1451, 2008.

HOMEDES, N.; UGALDE, A. Health reform and equity in Latin America. Ciência \& Saúde Coletiva, 16(6), 2690-2693, 2011.

KEMP, E. Under the veil of neoliberalism: Inequality, Health, en Capabilities. (Thesis of Master of arts), Simon Fraser University, Canada, 2008.

MEDINA, S.; MENDONÇA, M.; MANRIQUE, D. De discursos y exclusiones: una mirada a las zonas rurales del Sur de Chile. Paper presented at the V Reunião de Antropologia da Ciência e Tecnologia, Porto Alegre, Brasil, 2015. Retrieved from: http://ocs.ige.unicamp.br/ojs/react/article/view/1354/706

MENÉNDEZ, E. Modelos, experiencias y otras desventuras. In J. A. Haro (Ed.), Epidemiología sociocultural: un diálogo en torno a su sentido, métodos y alcances. Buenos Aires/Argentina: Lugar, 2010.

QUIJANO, A.; WALLERSTEIN, I. Americanity as a Concept or the Americas in the modern world-system. International Social Science Journal, 134(Nov), 549-557, 1992. 
RIVERO, D. Alma-Ata: 25 años después. Revista Perspectivas de Salud, 8(1), 2003.

SANTOS, B. A Crítica da Razão Indolente: Contra o Desperdício da Experiência. Porto: Afrontamento, 2000.

SANTOS, B. A natureza das globalizações. In B. Santos (Ed.), Globalização fatalidade ou utopia? (Vol. 1, pp. 56-76). Porto: Afrontamento, 2001.

SANTOS, B. Para uma sociologia das ausências e uma sociologia das emergências. In B. Santos (Ed.), Conhecimento Prudente para uma Vida Decente: "Um discurso sobre as Ciências" revisitado (pp. 735-775). Porto: Edições Afrontamento, 2003.

SANTOS, B. Globalizations. Theory, Culture \& Society, 23 (2-3), 393-399, 2006.

SILVA, C., GRANGEIRO, L., GURGEL, M., TEIXEIRA, N., MARTINS, P. \& ALBUQUERQUE, M. Experiência da organização da atenção à saúde mental no centro de saúde Alto da Brasília no município de Sobral-CE, SANARE - Revista de Políticas Públicas, 9(1), 51-54, 2010. Retrieved from https://sanare.emnuvens.com.br/sanare/article/view/209

STAKE, R. Case studies. In: Strategies of qualitative inquiry. DENZIN, N. K; LINCOLN, Y. S. (Ed.), Thousand Oaks: Sage publications, 2003.

UGALDE, A.; JACKSON, J. The World Bank and international health policy: A critical review. Journal of International Development, 7(3), 525-541, 1995.

WORLD HEALTH ORGANIZATION. Declaration of Alma-Ata. Paper presented at the International Conference on Primary Health Care, Alma-Ata, USSR, 1978. Retrieved from: http://www.who.int/hpr/NPH/docs/declaration_almaata.pdf

YIN, R. Estudo de Caso: Planejamento e Métodos, 4 ed, Porto Alegre: Bookman, 2010. YOUNG, R. Postcolonialism: A very short introduction. Oxford: Oxford University Press, 2003. 